\title{
Occupational health risk assessment of benzene and toluene at a landfill site in Johannesburg, South Africa
}

\author{
R. Moolla ${ }^{1}$, S. K. Valsamakis ${ }^{1}$, C. J. Curtis ${ }^{1} \&$ S. J. Piketh ${ }^{2}$ \\ ${ }^{I}$ School of Geography, Archaeology and Environmental Studies, \\ University of the Witwatersrand, South Africa \\ ${ }^{2}$ Department of Geography, North-West University, South Africa
}

\begin{abstract}
In developing countries land-filling is the most common form of waste management that is practiced. Landfills are known to be anthropogenic sources of air pollutants that have a negative impact on both environmental and human health. People who work on landfill sites are particularly at risk of adverse health effects associated with the inhalation of hazardous air pollutants (HAPs), such as volatile organic compounds (VOCs). Although VOCs only make up between $0.5 \%$ and $1 \%$ of total landfill gas, they are important due to the high level of toxicity associated with them. Regular air quality monitoring and hazard risk assessments provide important information that can be used in an effort to protect the health and safety of people working in a landfill environment. This is especially important within a developing context as relevant information is limited. In this study an occupational health risk assessment of benzene and toluene was conducted at a landfill in Johannesburg, South Africa. Applying an approach of modelling (using LandGEM) results indicated a significant increase in emission rates over a 90 year period. In addition, ambient air concentrations of BTEX, 100 meters from the landfill, were found to be unacceptable by US EPA air quality recommended standards. Additionally, cancer risk and hazard index calculations of benzene and toluene, of employees on-site, indicated that occupational exposures were above US EPA recommended standards. Thus, it was shown that employees were significantly at risk to adverse health effects associated with inhalation exposure to these HAPs.
\end{abstract}

Keywords: occupational health risk assessment, landfill, benzene, toluene. 


\section{Introduction}

In South Africa landfilling is the preferred method for managing Municipal Solid Waste (MSW) (Strachan and Tomaszewski [1]). Landfilling is the process in which MSW products are compacted and disposed of into a landfill. Landfills are a major source of Hazardous Air Pollutants (HAPs) that are known to have adverse health effects on exposed groups of people (Cointreau [2]; Davoli et al. [3]). VOCs are produced during anaerobic decomposition of hazardous components of MSW. Although VOCs occur in trace amounts in landfill gas, they are significant in that they are associated with a high level of toxicity at relatively small concentrations (Durmusoglu et al. [4]).

Inhaling air pollutants is the most direct exposure pathway to hazardous components on landfills. Air contaminants are able to reach the upper and lower portions of the lungs via inhalation. Inflammation and damage to the lungs and organ tissues occur through exposure to relatively high concentrations of contaminants or alternatively to low concentrations of contaminants over a long period (Elsom [5]; Bridges et al. [6]; Ezzati and Kammen [7]; Duarte-Davidson et al. [8]; Lindberg et al. [9]; Medina et al. [10]; Cointreau [2]; Kampa and Castanas [11]; Davoli et al. [3]; Durmusoglu et al. [4]). Due to this fact, it is imperative to conduct further analysis regarding occupational health, as workers are exposed on a daily basis to these emissions.

\subsection{Release of VOCs from landfills}

While there are many different types of VOCs present in landfill gas which vary significantly amongst different landfills, benzene, toluene, ethyl-benzene and xylenes (BTEX) are some of the most common VOC species present (Allen et al. [13]). According to Chiriac et al. [14] benzene and toluene gas are the most abundant of the BTEX group found in landfill gas.

Emissions from landfills mainly consist of methane ( $50-60 \%)$, carbon dioxide $(\sim 40 \%)$ and various non-methane organic compounds (NMOC's). However, emissions of known or suspected carcinogens and teratogens (VOCs, benzene, vinyl chloride, dioxins, and polycyclic aromatic hydrocarbons) also occur. Emissions containing hydrogen sulphide, mercury vapour, microbial pathogens, dust, and particulate matter are of specific concern (Vrijheid [12]). As these pose concerns regarding health, for workers and residents living in close proximity to landfills, many studies have evaluated their effects. However, these studies have mainly been conducted in North America and the United Kingdom (Vrijheid [12]). Studies have revealed that over 200 gas compounds are found in landfill sites.

In South Africa, the release of VOCs is exacerbated during different seasons. During the winter season a high pressure system is more prevalent, atmospheric conditions are more stable and vertical dispersion of pollutants is weaker. This allows gases to accumulate over the landfill site. During summer, a less dominant high pressure system is prevalent, atmospheric conditions are less stable and vertical dispersion of pollutants is stronger (Dickerson et al. [15]). 
Seasonal changes in temperature can also influence concentrations of VOCs. Higher temperatures can create conditions that sustain a high level of biological activity in the later stages of decomposition thus generating higher concentration of landfill gas. Cooler temperature in winter can also induce freezing (night) and thawing (day) processes which can disturb the surface upper layer allowing certain gases to escape (Chiriac et al. [14]). In addition, seasonal changes in rainfall can significantly influence concentrations of VOCs. Benzene and toluene for example, are removed from the atmosphere via wet deposition. Thus concentrations of benzene and toluene are likely to be lower during periods of high precipitation (Bhailall et al. [16]).

Duarte-Davidson et al. [8] emphasise that the disposal of benzene and toluene containing items in developing countries is common and often not well controlled, increasing the release of these substances. Municipal waste in South Africa is composed of a number of hazardous components such as: paints, batteries, electrical appliances, fluorescent light bulbs, oils, inks and cleaning products. These hazardous components are subject to a number of processes resulting in the release of hazardous substances in the form of a gas, liquid or solid. Benzene for example, is often used as a solvent for industrial purposes for removal of paints and degreasing purposes. It is frequently used in the production of rubber cements and arts and crafts. Disposal of benzene containing substances such as: building materials, inks, furniture materials and flooring products (glues) in a landfill allows benzene to be released as a component of landfill gas or leachate (Duarte-Davidson et al. [8]). Similarly toluene can be released from volatilisation and decomposition of waste that actually contains toluene compounds (paint thinners, solvents, nail polish, etc.).

\subsection{Health effects associated with exposure to benzene and toluene}

Benzene is a well-known carcinogenic component of landfill gas. Studies have shown that exposure to high concentrations of benzene can cause leukaemia, neurological effects, skin problems, respiratory problems and eye problems (Vrijheid [12]; Duarte-Davidson et al. [8]; Cointreau [2]; WHO [17]). A high risk of leukaemia can be expected when exposed to concentrations of benzene equal to or above $160 \mathrm{mg} / \mathrm{m}^{3} /$ year (Duarte-Davidson et al. [8]). Potential health effects depend on both concentration and period of exposure. Chronic illnesses are associated with exposure to small concentrations of benzene over a longer period of time. In fact Bridges et al. [6] and Vrijheid [12] argue that there should be no standard threshold limit for gases with carcinogenic properties because any level of exposure increases cancer risk.

Unlike benzene, toluene is non-carcinogenic and does not accumulate in body tissues (ATSDR [18]). Despite this, the United States Department of Health and Human Services confirms that exposure to high concentrations of toluene over a long period of time can cause headaches, drowsiness/sleepiness, kidney damage, intensified hearing loss, central nervous system damage, neurological effects, birth defects (including teratogenic effects) and respiratory irritation (Atari and Luginaah [19]). 
In South Africa literature regarding health impacts of landfills and their effects on humans is limited and reports that a large proportion of landfill gas comprises of methane and carbon dioxide. Regarding the health effects of gas release from landfills, these epidemiological studies have been conducted in developed countries that follow strict waste management strategies and laws, unlike South Africa. The studies include a range of research from looking at the effects of gas emission on the incidence of cancer (Jarup et al. [20]; Pukkala and Pönkä [21]; Russi et al. [22]); birth defects and reproductive disorders (Elliott et al. [23]; Elliott and Wartenberg [24]; Gilbreath and Kaas [25]; Jarup et al. [26]; Kloppenborg et al. [27]; Saunders [28]); respiratory diseases (Pukkala and Pönkä [21]).

The aim of this paper is to analyse exposure and inhalation risk of occupational workers at a landfill in South Africa. It will outline the methodology used to analyse a preliminary occupational health risk assessment conducted in a pilot study in Johannesburg. The study focuses on occupational health risks with exposure to benzene and toluene gas within a developing context.

\section{Background}

In South Africa waste is managed according to the minimum requirements laid down by the Government in the National Waste Management Strategy (NWMS) and the National Environmental Management Waste Act (Act 59 of 2008).

South Africa, a developing country, is ahead when compared to other African countries in terms of formally converting open dump sites into landfills since the first Minimum Requirements for Landfilling Waste was published in 1994. The Minimum Requirements maintains that a landfill should be classified according to characteristics of waste types, size of waste stream and climatic water balance (Strachan and Tomaszewski [1]). As a result South Africa is one of the few African countries that have a suitable framework for managing waste efficiently. However, landfill gas management practices in South Africa are still poor compared to most developed countries MSW landfills.

\subsection{Site description}

The study site is Turffontein, south of Johannesburg. The landfill first started accepting waste in 1930 (the site first served as an old gold mine tailings dam, or slimes dam, prior to 1930). It is predicted to close in 2031, and currently has a surface area of 124 hectares. The site is currently operated by the local municipality, Pikitup Ltd. It is classified as a $\mathrm{GLB}^{-}$(general, large waste, no significant leachate) landfill site that is situated upon layers of shale, clay and sandstone. The site is surrounded by a combination of residential and industrial areas. 


\section{Methodology}

For this study a combined approach was employed, using historical landfill composition/amount data to model landfill gas emissions, and measured ambient concentrations of benzene and toluene to calculate current cancer risk and hazard risk for benzene and toluene. Landfill staff interviews were used to obtain data on current and cumulative exposure to landfill gas emissions.

\subsection{Landfill Gas Emissions Model (LandGEM)}

Benzene and toluene gas emission rates were estimated using the Landfill Gas Emissions Model (LandGEM V7.0). Input parameters were chosen based on site characteristics. Hence co-disposal of hazardous and non-hazardous waste was assumed. This was due to the fact that the site first served as a gold mine slimes dam prior to a waste disposal site. Default values for methane generation rate constant $(\mathrm{k})$ and the methane generation potential $\left(\mathrm{L}_{0}\right)$ were used (Chalvatzaki and Lazaridis [30]).

Estimates of landfill gas production rates were based on yearly solid waste acceptance rates for the period of 1930-2010. Waste fractions (kg) were provided for by Pikitup for the period of 2003-2010 (for the period 1930-2002 rates were extrapolated).

\subsection{Risk calculations}

Benzene and toluene are important VOCs present in landfill gas emissions because of the high level of toxicity associated with them. Due to the fact that benzene is a carcinogenic agent (Group A) and toluene is a non-carcinogenic agent (Group D); both cancer risk and hazard risk (associated with the inhalation of air pollutants) calculations were done for 10 individual employees to evaluate the effect of each pollutant respectively. Individual calculated cancer risk and hazard risk values were compared with US EPA acceptable standards.

To calculate cancer risk eqn (2) was applied, whereas eqn (3) was used to evaluate hazard risk:

$$
\begin{aligned}
& \text { Cancer risk }=\text { Intake }(I) x \text { carcinogens potency factor }(C P F) \\
& \text { Hazard risk }=\text { Intake }(I) / \text { reference dose }(R F D)
\end{aligned}
$$

CPF and RFD standard values were used [benzene $0.029 \mathrm{mg} \mathrm{kg}^{-1}$ day $^{-1}$ and toluene $1.43 \mathrm{mg} \mathrm{kg}^{-1} \mathrm{day}^{-1}$ ] (Durmusoglu et al. [4]).

To calculate the intake eqn (4) was utilised:

$$
I=(C . C F . I R \cdot E F . E D) /(B W . A T)
$$

where the parameters can be defined as:

- $\mathrm{C}$ is the contaminant concentration (average eight-hourly concentrations were collected using the SYNSPEC Spectras GC 955 analyser and measured continuously per season. Data was provided for by the 
University of the Witwatersrand's former Climatology Research Group for the late autumn/winter period of 2010) $\left[\mu \mathrm{g} / \mathrm{m}^{3}\right]$;

- $\quad \mathrm{CF}$ is the conversion factor $[1 \mathrm{mg} / 1000 \mu \mathrm{g}]$;

- IR is the inhalation rate (US EPA standard) $\left[20 \mathrm{~m}^{3} / \mathrm{day}\right]$;

- $\quad \mathrm{EF}$ is the exposure frequency [day/year];

- $\quad$ ED is the exposure duration [years];

- $\mathrm{BW}$ is body weight (US EPA standard) [70kg];

- $\quad$ AT is the averaging time (exposure averaged over life time/ average life expectancy for male and female) [days].

\subsection{Interviews}

Ten interviews were conducted in order to provide information pertaining to individual input variables such as age, sex, exposure frequency and exposure duration. Where data were limited due to ethical restrictions US EPA standard values were used [for body weight $(70 \mathrm{~kg})$ and inhalation rate $\left(20 \mathrm{~m}^{3} / \mathrm{day}\right)$ ] (Durmusoglu et al. [4]). In addition it was assumed that all employees worked a standard of eight hours per day and received a minimum of 21 days leave each year. More detailed evaluation of confounding factors was beyond the scope of this study.

Thus to calculate exposure frequency (EF) eqn (5) was used:

[52*(number of days worked/3)]- Number of days leave

where values represent:

- $52=$ weeks in a year

- $3=24$ hours in a day/8 hours of work

\section{Results and discussion}

\subsection{Benzene and toluene emission rates}

Modelling of HAPS from landfills can provide insightful projections for future conditions, which may aid in the minimisation of potential implications before the effects become irreversible. Modelled emission rates for benzene and toluene show a significant increase for 1930-2020 at the study site (the results are based on expected future waste fractions) (Figure 1). Rates of production for benzene and toluene rapidly increased from 1970; and are expected to reach a peak of $4.89 \mathrm{Mg} /$ year and $89.00 \mathrm{Mg} /$ year respectively in 2020 . There is little information describing emission rates of benzene and toluene over landfills in South Africa. Nonetheless, the projected maximum production rate of benzene is comparable to that of the Ano Liosia landfill in Athens in the results of Paraskaki and Lazaridis [30]. However, there was no active gas collection system installed at Ano Liosia and one only recently installed at the Johannesburg landfill. 


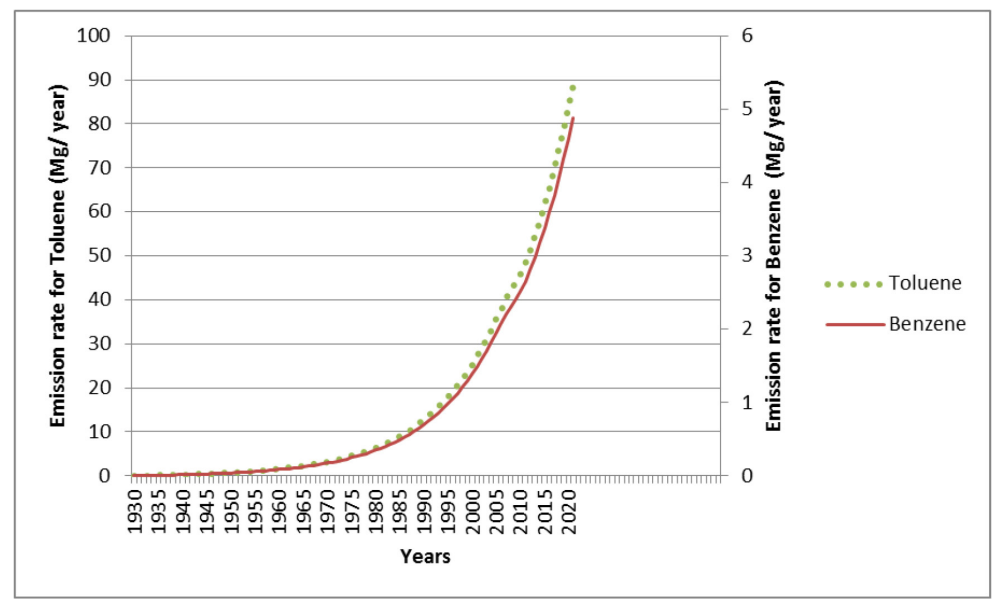

Figure 1: $\quad$ Modelled emission rates of benzene and toluene for the landfill site for 1930-2020. There is a slight variation in emission rates of the gases as anaerobic decomposition of benzene occurs at a slower rate than toluene.

At the landfill there has been no gas collection system for the period of 19302011. Landfills with no active gas collection systems are associated with higher emission rates of VOCs compared to landfills with an active gas collection system (Di Bella et al. [31]). Over time VOCs become less prevalent and methane and carbon dioxide are more prevalent (Chiriac et al. [14]). Thus VOCs only account for a small portion of landfill gas that is being produced. However, pollutant concentrations for benzene and toluene at the landfill in 2010 were found to be ten times higher than that of US EPA's 8 hour recommended standards. Benzene and toluene recommended standards are $166.1008 \mathrm{mg} / \mathrm{m}^{3}$ and $753.71 \mathrm{mg} / \mathrm{m}^{3}$, while pollutant concentrations were found to be $1987.08 \mathrm{mg} / \mathrm{m}^{3}$ and $9446.71 \mathrm{mg} / \mathrm{m}^{3}$ respectively for the year. It can be inferred that people exposed to higher emission rates of VOCs are possibly at risk of adverse health effects (Bridges et al. [6]).

\subsection{Cancer risk and hazard risk calculations}

In order to assess whether these emissions would have an effect on employees, the risks were evaluated. All employees interviewed had been employed for a minimum of two years. Respondents two and four had both worked on the site for 25 years. All employees worked at least five days a week. Only respondents two and three stated that they worked on site six days a week. Thus based on the above information, both respondents two and three had a maximum exposure frequency of 83 days/year each (Table 1).

Risks were based on the assumption that pollutant concentrations were linearly comparable to modelled emission rates. Thus, using base line concentrations of benzene and toluene of $1987.08 \mathrm{mg} / \mathrm{m}^{3}$ and $9446.71 \mathrm{mg} / \mathrm{m}^{3}$ 
respectively for 2010; exposure of each respondent was scaled using the modelled emissions. Cancer risks were characterised for each respondent exposed to benzene emissions on site and were found to be above the US EPA standard of 0.0004 (Durmusoglu et al. [4]), for all respondents (Figure 2). Respondents two and four both had unacceptably high cancer risks of 1.028795 and 0.813946 respectively, while other respondents had a level of risk marginally below respondents two and four.

Table 1: $\quad$ Attribute information for interviewees.

\begin{tabular}{|c|l|c|c|c|c|c|c|c|c|c|c|}
\hline & RESPONDENTNUMBER & $\mathbf{1}$ & $\mathbf{2}$ & $\mathbf{3}$ & $\mathbf{4}$ & $\mathbf{5}$ & $\mathbf{6}$ & $\mathbf{7}$ & $\mathbf{8}$ & $\mathbf{9}$ & $\mathbf{1 0}$ \\
\hline \multirow{2}{*}{} & Exposure frequency (day/year) & 65.67 & 83.00 & 83.00 & 65.67 & 65.67 & 65.67 & 65.67 & 65.67 & 65.67 & 65.67 \\
& Exposure duration (years) & 2.5 & 25 & 2.5 & 25 & 7.5 & 2.5 & 7.5 & 7.5 & 7.5 & 2.5 \\
& Age & 40 & 51 & 36 & 50 & 32 & 32 & 56 & 32 & 27 & 28 \\
\hline & Sex & $\mathrm{f}$ & $\mathrm{m}$ & $\mathrm{m}$ & $\mathrm{m}$ & $\mathrm{m}$ & $\mathrm{m}$ & $\mathrm{m}$ & $\mathrm{m}$ & $\mathrm{m}$ & $\mathrm{m}$ \\
\hline
\end{tabular}

Hazard risks (non-cancer risk) were above the US EPA standard of 1 (Durmusoglu et al. [4]; Tunsaringkarn et al. [32]) for all respondents (Figure 3). Therefore hazard risks for all respondents were considered unacceptable. Thus it was found that the landfill in Johannesburg poses a major occupational risk to all employees. In addition estimates for 2020 , based on modelled results, indicated that cancer risks range from 1.11-4.53 and hazard risks range from 262.50 840.29 for employees in service for the additional eight years (the significant range is due to the fact that years of employment range from an expected 10.533 years of service at the landfill in 2020). This implies increased risks of $98 \%$ from 2010 baseline results.

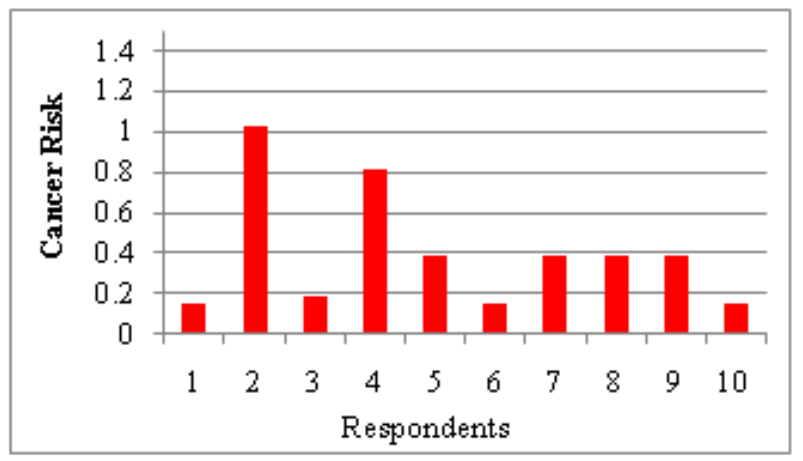

Figure 2: Cancer risk for employees exposed to benzene. The US EPA standard is 0.0004, indicating that cancer risk is above the guideline value for all employees. 


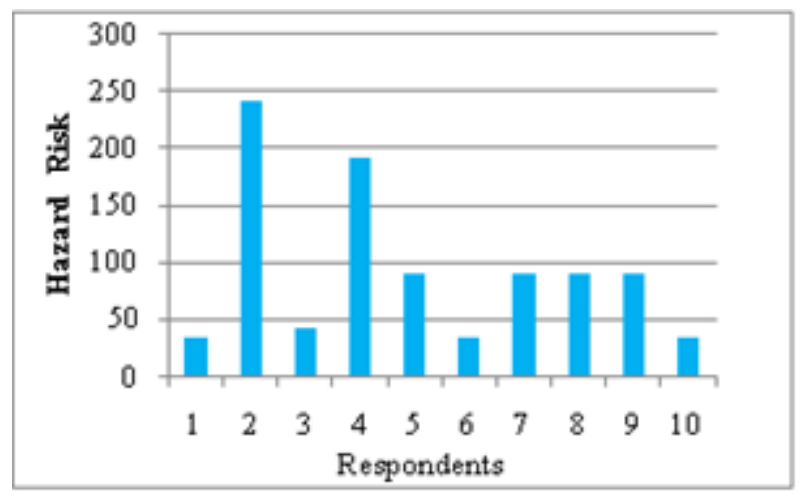

Figure 3: Hazard risk for employees exposed to toluene. The US EPA standard is 1 , indicating that cancer risk is above the guideline value for all employees.

It has been argued in many studies that people who have been exposed to concentrations of HAPs within acceptable air quality standards are safe from adverse health effects (Elsom [5]; Bridges et al. [6]; Duarte-Davidson et al. [8]; Medina et al. [10]; Cointreau [2]; Kampa and Castanas [11]). However, as shown all respondents, people who have been exposed to above acceptable levels of benzene over any period of time are at risk to adverse health effects. DuarteDavidson et al. [8]) show that repeated exposure to benzene can cause acute nonlymphocytic leukaemia because benzene is able to accumulate in the body. Furthermore, they suggest that people who are repeatedly exposed to benzene are at risk of problems with production of bone marrow, white blood and red blood cells, cancer and chromosomal malformations (Duarte-Davidson et al. [8]).

Toluene on the other hand is not able to accumulate in the body and within 12 hours after exposure $75 \%$ of toluene is removed from the body (ATSDR [18]). Therefore, people who are exposed to below threshold concentrations of toluene are safe from adverse health effects. Conversely, with the high level of calculated hazard risks for each respondent, repeated exposure to toluene can cause permanent damage to heart, kidneys, liver, lungs and central nervous system (Mckeown [33]). Furthermore, calculated cancer and hazard risks are limited in that assumptions were made based on US EPA standard values with respect to body weight, inhalation rate and amount of hours worked and could be underestimated. Similarly confounding factors such as smoking, level of fitness or exposure to other sources of benzene and toluene and alternative exposure routes (digestion or skin absorption) were not considered as this was beyond the scope of this study. There is a need for further epidemiological studies investigating possible health effects of exposed occupational workers to benzene and toluene at this landfill site; however estimated risks are very high. 


\section{Conclusion}

In conclusion landfill sites are a major source of HAPs. People who work on landfills are exposed to HAPs via the inhalation of landfill gas. People who are exposed to above standard concentrations of VOCs are at risk of adverse health effects. In developing countries information of this sort is limited. Thus an occupational health risk assessment was conducted for a single landfill site in Johannesburg, South Africa.

According to the model, production rates of benzene and toluene were shown to have increased since 1930, while pollutant concentrations in 2010 were above all US EPA recommended standards (24 hour; 8 hour and annual recommendations). Additionally, cancer risk and hazard risk were characterised for employees exposed to benzene and toluene. All respondents had unacceptable cancer and hazard risks. Thus, it was shown that employees were significantly at risk to adverse health effects associated with inhalation exposure to these HAPs.

However, cancer risks and hazard risk calculation could be under- or overestimated due to the limited amount of data that could be obtained, and the fact that results were based on an assumption that modelled and measured concentrations were linear. Thus further research needs to be done to accurately evaluate cancer risks and hazard risks associated with occupational exposure to benzene and toluene at the landfill site.

\section{Acknowledgements}

The authors would like to thank the National Research Foundation for funding provided for this project; Pikitup for baseline data; and the former Climatology Research Group for the use of BTEX concentrations from 2010.

\section{References}

[1] Strachan, L.J. and Tomaszewski, T., Beyond Landfills: A new age of maximising the value of waste as a renewable energy and job creation resource in South Africa. Government Digest, 2, pp. 2-5, 2009.

[2] Cointreau, S., Occupational and Environmental health Issues of solid Waste Management. The World Bank, Washington DC, 2006.

[3] Davoli, E., Fattore, E., Paiano, V., Colombo, A., Palmiotto, M., Rossi, A.N., Il Grande, M. and Fanelli, R., Waste management health risk assessment: A case study of a solid waste landfill in South Italy, Waste Management, 30, pp. 1608-1613, 2010.

[4] Durmusoglu, E. Taspinar, F. and Karademir, A., Health risk assessment of BTEX emissions in the landfill environment. Journal of Hazardous Materials, 176, pp. 870-877, 2010.

[5] Elsom, D., Smog alert: Managing urban air quality, Earthscan Publications Limited, London, 1996. 
[6] Bridges, O., Bridges, J.W. and Potter, J.F., A generic comparison of the airborne risks to human health from landfill and incinerator disposal of MSW, The Environmentalist, 20, pp. 325-334, 2000.

[7] Ezzati, M. and Kammen, D.M., Indoor Air pollution from biomass combustion and acute respiratory infection in Kenya: an exposureresponse study. The Lancet, 358, pp. 619-624, 2001.

[8] Duarte-Davidson, R., Courage, C., Rushton, L. and Levy, L., Benzene in the environment: an assessment of the potential risks to the health of the population. Occupational Environment Medical, 58, pp. 2-13, 2001.

[9] Lindberg, S.E., Wallschlager, D., Prestbo, E.M., Bloom, N.S., Price, J. and Reinhart, D., Methylated mercury species in municipal waste landfill gas sampled in Florida, USA. Atmospheric Environment, 35, pp. 4011-4015, 2001.

[10] Medina, S., Plasencia, A., Ballester, F., Mucke, H.G. and Schwartz, J., Aphesis: Public health impact of the $\mathrm{PM}_{10}$ in 19 European cities. Journal of Epidemiology Community Health, 58, pp. 831-836, 2004.

[11] Kampa, M. and Castanas, E., Human health effect of air pollution. Environmental Pollution, 151, pp. 362-367, 2008.

[12] Vrijheid, M., Health effects of residence near hazardous waste landfill sites: A review of epidemiologic literature. Environmental Health Perspectives, 108 (1), pp. 101-112, 2000.

[13] Allen, M.R., Braithwaite, A., Hills, C.C., Trace Organic Compounds in Landfill Gas at Seven U.K. Waste Disposal Sites. Environmental Science and Technology, 31(4), pp. 1054-1061, 1997.

[14] Chiriac, R., Morais, J.D., Carre, J., Bayard, R., Chovelon, J.M. and Gourdon, R., Study of the VOC emissions from a MSW storage pilot-scale cell: Comparison with biogases from municipal waste landfill site. Waste Management, 31, pp. 2294-2301, 2011.

[15] Dickerson, R. R., Huffman, G. J., Luke, W. T., Nunnermacker, L. J., Pickering, K. E., Leslie, A. C. D., Lindsey, C. G., Slinn, W. G. N., Kelly, T. J., Daum, P. H., Delany, A. C., Greenberg, J. P., Zimmerman, P. R., Boatman, J. F., Ray, J. D. and Stedman, D.H., 1987: Thunderstorms: An important mechanism in the transport of air pollutants. Science, 235, 460$465,1987$.

[16] Bhailall, S., Piketh, S., Smith, N., Bogner, J., Subsurface gas generation at a landfill in Johannesburg. Clean Air Journal, 18(1), pp.10-14, 2010.

[17] World Health Organisation, Chapter 3: Air quality standards and objectives, 2012. www.WHO.org

[18] Agency for Toxic Substances and Disease Registry (ATSDR), Toxicological Profile for Toluene. www.atsdr.cclo.gov/toxfaqs $/$ tf.asp?id=160\&tid=29

[19] Atari, D.O. and Luginaah, I.N., Assessing the distribution of volatile organic compounds using land use regression in Sarina, "chemical valley", Ontario, Canada. Environmental Health, 8, pp. 16-30, 2009.

[20] Jarup, L., Briggs, D., de Hoogh, C., Morris, S., Hurt, C., Lewin, A., Maitland, I., Richardson, S., Wakefield, J., Elliott, P., Cancer risks in 
populations living near landfill sites in Great Britain. British Journal Cancer, 86, pp. 1732-1736, 2002.

[21] Pukkala, E., Pönkä, A., Increased incidence of cancer and asthma in houses built on a former dump area. Environmental Health Respect, 109, pp. 1121-1125, 2001.

[22] Russi, M.B., Borak, J.B., Cullen, M.R., An examination of cancer epidemiology studies among populations living close to toxic waste sites. Environmental Health, 26, pp. 7-32, 2008.

[23] Elliott, P., Briggs, D., Morris, S., de Hoogh, C., Hurt, C., Jensen, T.K., Maitland, I., Richardson, S., Wakefield, J., Jarup, L., Risk of adverse birth outcomes in populations living near landfill sites. British Medical Journal, 323, pp. 363-368, 2001.

[24] Elliott, P. and Wartenberg, D., Spatial epidemiology: Current approaches and future challenges. Environ. Health Perspective. 112, pp. 998-1006, 2004.

[25] Gilbreath, S., Kaas, P.H., Adverse birth outcomes associated with open dumpsites in Alaska native villages. American Journal of Epidemiology, 164, pp. 518-528, 2006.

[26] Jarup, L., Morris, S., Richardson, S., Briggs, D., Cobley, N., de Hoog, C., Gorog, K., Elliot, P., Down Syndrome in births near landfill sites. Prenatal Diagnoses, 27, pp. 1191-1196, 2007.

[27] Kloppenborg, S.C., Brandt, U.K., Gulis, G., Ejstrud, B., Risk of Congenital anomalies in the vicinity of waste landfills in Denmark; an epidemiological study using GIS. Central European Journal of Public Health, 13, pp. 137-143, 2005.

[28] Saunders P: A systematic review of the evidence of an increased risk of adverse birth outcomes in populations living in the vicinity of landfill waste disposal sites. In F., Mitis, M., Martuzzi (Eds). Population health and waste management: scientific data and policy options. Report of a WHO workshop Rome, Italy, 2007

[29] Chalvatzaki, E. and Lazaridis, M., Assessment of air pollutant emissions from the Akrotiri landfill site (Chania, Greece). Waste Management \& Research, 28, pp. 776-778, 2010.

[30] Paraskaki, I. and Lazaridis, M., Quantification of landfill emissions to air: a case study of the Ano Liosia landfill site in the greater Athens area. Waste management Resolutions, 23, pp. 199-208, 2005.

[31] Di Bella, G., Di Trapani, D. and Viviani, G., Evaluation of methane emissions from Palermo municipal landfill: Comparison between field measurements and models. Waste Management, 31, pp. 1820-1826, 2011.

[32] Tunsaringkarn, T., Prueksasit, T., Kitwattanavong, M., Siriwong, W., Sematong, S., Zapuang, K. and Rungsiyothin, A., Cancer risk analysis of benzene, formaldehyde and acetaldehyde on gasoline station workers Journal of Environmental Engineering and Ecological Science, 1, 2012. http://dx.doi.org/10.7243/2050-1323-1-1

[33] Mckeown, N.J., Drugs, Diseases and procedures, Toluene Toxicity, 2011. www.emedicine.medscape.com/article1818939-overview1I901999./2012/ 